\title{
Multifarious facets in the thinking of the elusive Friedrich Schleiermacher (21 November 1768 - 12 February 1834)
}

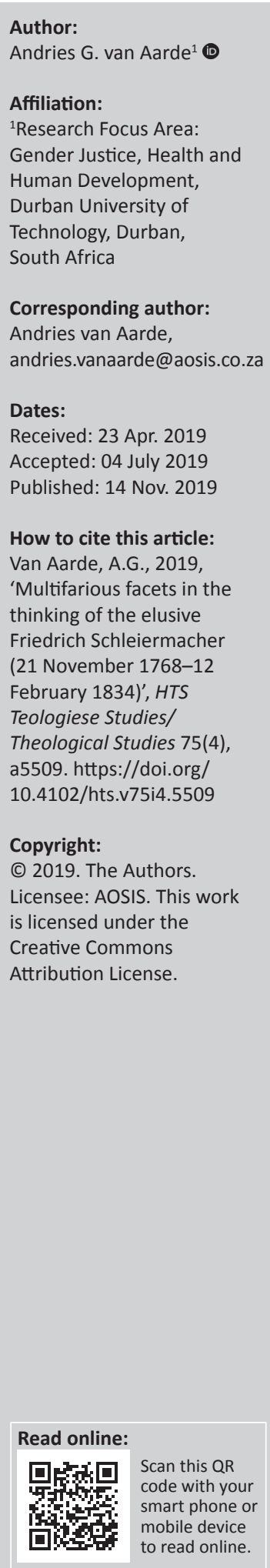

This article forms part of the commemoration of Friedrich Schleiermacher, who died 185 years ago on 12 February 1834. It focuses on the aspects of Schleiermacher's life and work that have influenced the author the most. The article consists of personal annotations, Schleiermacher's understanding of 'divine' hermeneutics, his notion of congeniality and his 'subscription' to creedal Christianity while promoting the freedom of the exegete to interpret the Bible and ecclesiastical confessions robustly and critically.

Keywords: Friedrich Schleiermacher; Hermeneutics; Congeniality; Subscription to confessions; Theōsis.

\section{Introduction}

Theologian and philosopher Friedrich Schleiermacher, like none other, had a knack for reformulating his previous ideas to better elucidate their 'original' intention. An avid reader of Schleiermacher's work will have to be cognisant of the fact that the editions of his work will differ. This contributes to the 'elusiveness' of Schleiermacher and his theological philosophy. However, it also attests to the progressive nature of his personhood and work. It also gives an indication of who he was in real life. The goal of this thinking was always the journey rather than the destination. He would constantly rethink and reformulate insights he had conceptualised before.

Initially, my intention with this article was to focus on the work of Geoff Dumbreck (2012) and his analytical explanations of the 'alterations' Schleiermacher made to earlier conceptualisations (e.g. Dumbreck 2012:86-87).

Examples are the notions of 'absolute dependence' (Dumbreck 2012:106-107) and Anschauung (intuition) (Dumbreck 2012:191). Dumbreck also reflects specifically on the Wirkungsgeschichte of Schleiermacher's understanding of the 'essence of religion' and 'religious feeling'. His influence can be seen, among others, in the work of William James ([1902] 2012) and Rudolf Otto ([1917] [1923] 1958) (see Dumbreck 2012:139-162).

Both James and Otto are scholars for whom I also have a deep appreciation.

My aim was, at first, to illustrate why I regard Schleiermacher as the 'harbinger' of present-day postmodern posttheism. Jon Sydnor (Emmanuel College in Boston) (2011:106), in his comparison between the work of Schleiermacher from the Christian tradition and that of Sri Ramanuja from the Hindu tradition, emphasises that, for Schleiermacher, 'God is not an object but the source of all objects'. According to Schleiermacher, 'God must be felt before God can be thought' (Sydnor 2011:106). However, a reflection on the broad objectives of post-theism and panentheism would go beyond the scope of the possibility which this symposium offers. I therefore changed my goal. In this commemoration of Schleiermacher who died 250 years ago, I would rather like to highlight those aspects of his life and work that have influenced me most. I begin with some personal existential remarks. The end of the article could appear rather abrupt. However, that is precisely my intention: an 'in-conclusion', an open end, with Schleiermacher speaking through one of his characters with whom I can identify - a fusion of horizons.

\section{Personal annotations}

Karl Barth (1886-1968), in his critical tribute to Schleiermacher (Barth [1968] [1978] 1982:3), refers to Leopold von Ranke's (1795-1886) account of Schleiermacher's funeral in Berlin on

Note: Engaging Schleiermacher today: South African perspectives, sub-edited by Rian Venter (University of the Free State). 
21 November 1834, which was attended by between 20000 and 30000 people. Schleiermacher was the central theme in my inauguration speech as Chair of the Department of New Testament Studies at the University of Pretoria on 02 November 1989. I referred to philosopher Heinrich Steffens' (1773-1845) comment at the funeral that Schleiermacher had lectured and preached until his voice was hoarse (Van Aarde 1989:15-16). On Sunday, 26 January, he led the service for the last time. A week later he conducted his last morning devotion on Sunday, 02 February. In that same week, on Thursday, 06 February, he gave his last lecture. He fell ill the next day on Friday, 07 February, and died a fortnight later on Wednesday, 22nd February. On his deathbed, he requested that his family celebrate Holy Communion with him (Barth [1952] 1972:432). In my inauguration speech, I reflected on Schleiermacher's 'trialectic' Wissen - Tun - Gefühl. Schleiermacher's profound insightthatfeeling ('dasschlechthinnigeAbhängigkeitsgefühl') is the heart of religiosity - but always dialectically connected with head, hands and feet - has had a great influence on my life, to the extent that I can say unequivocally: Schleiermacher was and is my role model.

I have always preferred Kantian dialectics to that of Hegel. With Schleiermacher, I dislike Hegel's 'closed patternising' way of thinking and much prefer Kantian 'openness' (cf. inter alia Andreas Arendt 2010:356-360).

Today, I recognise the dialectic between heart and hand or feet as a significant metaphorical feature of 'biblical anatomy' and indispensable to spiritual healing and wholeness. I was inspired to translate Schleiermacher's Die Weihnachtsfeier: Ein Gespräch from his Prussian-Gothic German into Afrikaans (Van Aarde 2003) because I regard it as one of the best theological achievements of the 19th century. I wanted to make it more accessible. In 2010, one of the eminent Schleiermacher scholars today, Terence Tice, commended this translation as a contribution to Schleiermacher studies. In the journal Pastoral Psychology (2015), Wayne Rollins (Hartford Seminary, CT), one of the pioneers of psychological biblical criticism, expresses his appreciation of my explanation of how Schleiermacher applied psychology to biblical exegesis (Rollins 2015:510-511; Van Aarde 2015:481-492).

Systematic theologian Wentzel van Huyssteen, known for his studies on the evolution of consciousness and spirituality in humankind, is currently focusing on Schleiermacher's contribution. In a telephonic conversation in 2017, he expressed his joy in my emphasis on 'God-consciousness' in Schleiermacher's work (see Van Aarde 2016:29-58).

However, I have also been critical of Schleiermacher's emphasis on the significance of langue ${ }^{1}$ and how that could have contributed to the rise of the ideology of German nationalism. This was discussed by a panel reflecting on

1.Using Ferdinand de Saussure's [1857-1913] distinction between 'langue' as a universal phenomenon, 'language' as referring to the language of a particular group of people and 'parole' as a singular use of a specific language (for example, a 'dialect or features thereof) by an individual or a group of people.
Norwegian scholar Halvor Moxnes' book, Jesus and the Rise of Nationalism: A New Quest for the Nineteenth Century Historical Jesus (I.B. Tauris 2012) in Chicago in 2013. The panel discussion was published as an article in 2013 in Italy (Kazen et al. 2016:193-234). However, the ideology criticism of both Moxnes and myself can be mitigated somewhat when one considers the use of the concept of language and the notion Einfühlung and Einverständnis - empathy through agreement by the anti-Nazi scholars Ernst Fuchs and Gerhard Ebeling in their 'new hermeneutics' approach relied heavily on Schleiermacher's (and Bultmann's and Dilthey's) hermeneutics (see Van Aarde \& Van Wyk 2016; Van Wyk \& Van Aarde 2016).

The same goes for Paul Ricoeur's use of the notion 'refiguration' in his narratology. It was only after the discussion in Chicago that I read the section 'Signposts of a public theologian' in Richard Crouter's (2005:123-194) book, Friedrich Schleiermacher: Between Enlightenment and Romanticism. Crouter finally appeases my suspicion when he points out that Schleiermacher's position as professor in Berlin was in danger because of his criticism of the imperial monarchy for interfering with academic freedom and his disdain for the hegemony of the authorities who attempted to silence the voices of students. Crouter (2005:169-194) also discusses Schleiermacher's promotion of the freedom of the peasantry and the 'emancipation' of Jews, as well as his anti-conventional friendship with the Jewish woman Henriette Herz and the married woman, Eleonore Grunow.

Schleiermacher's work on language also exhibited a sensibility for what was later called feminist perspectives. He transformed male-dominated semantics by changing the focus on sexuality in the German word Schämigkeit (in Afrikaans: 'kuisheid') to Respekt for women and their equality as human beings (see Drucilla Richardson 1991:133-164). In a letter to his sister Charlotte von Kathen, he expresses the 'impossible wish' that he could be a woman. One of his biographers, Keith Clements (1987), remarks:

The reason Schleiermacher gives for this fantasy, however, should be noted. It is the opportunity, as he sees it, for women to retain inner feelings of love and imagination as compared with men who are so quickly lost and occupied in activity. (p. 22)

\section{'Divine' hermeneutics}

For me, narrative criticism has always been closely connected with unrestricted historical criticism and what I call 'engaged hermeneutics' when reading life stories in the Bible.

In 1819, Schleiermacher became the first biblical scholar and philosopher of the Enlightenment to reflect hermeneutically on criteria for authentic biography. The work, The Life of Jesus, consists of lectures on Jesus' life history that were assembled posthumously. Issues such as whether the biography of a specific individual should be investigated in terms of a comprehensive framework are considered (see Schleiermacher [2009] 2016:27-42). For example, should a biography include 
the inner circle of people with whom the individual interacted as well as the social, geographical, political, economic, and religious contexts? What role do the researcher's preunderstanding and pre-suppositions play with regard to the subject of the research? From a methodological point of view, criteria would then include social, theological and psychological concerns. In Schleiermacher's sophisticated hermeneutics, the divinatory is the point of departure. For him, the quality of the 'divinatory' ('divining' meaning guessing) depends on how astute the interpreter is a rare talent. As interpretation is also practised by the less talented and can be learnt, that special art of truly gifted interpreters should be laid down in methods. These methods should be retained as the rules of interpretation (in Schleiermacher's terms, the 'edifice' of exegetical conventions').

Gifted interpreters succeed in experiencing the spirit of ancient texts. For the gifted interpreter, this seems to come naturally. However, the interpreter is then challenged to articulate this feeling so that other can either also experience or at least learn about it. In this way, they can internalise the power of the spirit of the text and communicate it further. They repeatedly experience the enjoyment of the dynamics and wonder (Zauber) of bygone cultures (Schleiermacher [1927-1928] 1985:127-1230). The divinatory therefore consists of post-feeling, post-understanding, post-enjoyment, in the sense of re-experiencing the psychological dynamics of life. For him, the aim of hermeneutics is understanding to gain some measure of certainty and avoid misunderstanding.

Divine understanding should be distinguished from demonstrative understanding. Divine understanding rests on probability, whereas demonstrative understanding is a more positive historical approach. This is why Schleiermacher distinguishes between grammatische Hermeneutik and psychologische Hermeneutik (Lang 1873). Grammatical interpretation investigates language and history. The process of interpretation has an objective focal point. Psychological hermeneutics investigates language as the expression of an individual author. However, the distinction between 'grammatical interpretation' and 'psychological interpretation' should not be confused with the distinction between demonstrative and divine interpretation. 'Demonstrative' and 'divine' understandings are found in both psychological and grammatical interpretations. Demonstrative understanding is gained by means of an exegetical investigation. The unknown is revealed in language. The interpreter communicates the newly discovered insight through the lens of what is already known. This process is hermeneutically circular: the particular is explained through the universal, or the whole through the part. In such a hermeneutically circular process, the unknown is eliminated. However, the communicative ideal, namely, to reach some form of commonality, is never accomplished fully. 'Divining' remains guessing. That reality can never change. Where demonstrative understanding emphasises the universal ideal of communication to reach common agreement, divine understanding emphasises the relevance of individuality, which is the psychological existentiality of a person.

\section{Congeniality}

Schleiermacher brought about a new direction in the reflection on hermeneutics. He no only maintained the grammatical-historical interpretation of the scriptures, but also linked it to a psychological understanding of the texts. For him, history is the manifestation of religious consciousness in individual forms. So, also, biblical texts are evidence of 'pious' states of consciousness expressed in language. The ever-present possibility of misunderstanding is a reality of interpretation. The reason for this is the individuality of people who express themselves in a spoken or written form of language.

The spirituality or consciousness of a unique individual is not directly accessible to listeners or readers. They remain strangers or outsiders to the individual's spirituality. Those who are familiar with the linguistic conventions can think that they understand, but most probably they too do not entirely grasp what is being communicated. The 'strangeness' between them can be overcome by authentic understanding. This requires more than simply being familiar with linguistic conventions. What is required is an appropriation of the ideas that are expressed in words.

Ideally, the true intention should be grasped by means of an existential appropriation of the substance of the meaning of what the other dialogue partner communicates. To grasp 'true intention', one should be able to reproduce the 'origin' of the thought. This can only be done through the linguistic conventions at one's disposal.

According to Schleiermacher, apart from the 'strangeness' between them, there is also a fundamental bond between the communication partners. He calls this congeniality a commonality of spirit, which enables one to 'empathise' with or 'immerse' oneself in the conscious life of the other. This congeniality is based on the 'general human nature' that all people share. The essence of understanding is to change the strange, different and individual to the familiar, same and communal. This is done by respecting difference rather than attempting to destroy it.

Understanding is not about eliminating individuality to achieve the communal. The individual's observation is never completely understood. The understanding can always be corrected. The individuality of the text can never become obsolete. Understanding, therefore, presupposes finite knowledge. There is no absolute certainty, only a relative certainty. The tension between familiarity and strangeness remains.

Wilhelm Dilthey ([1894] 1977, in Christensen [1998] [2004] 2018) explains Schleiermacher's view as follows:

Individualities are not distinguished from one another by the presence of qualitative determinations or by certain modes of connection in one which would not be in the others ... The uniformity of human nature is manifested in the fact that the same qualitative determinations and forms of connection appear 
with all men [sic] (where no abnormal defects exist). But the quantitative relationships in which they are presented are very different from one another; these differences are combined into ever new combinations on which depend, then, first of all, the differences of individualities. (p. 5 of 17)

The more creative people are, the greater their individuality and the more unique their thoughts. This leads to different levels of congeniality. According to Dilthey, Schleiermacher emphasises that we 'realise our own individuality through insight (Anschauung) into the individuality of others' (Christensen 2018:2 of 17).

Schleiermacher's notion of 'congeniality' has influenced my hermeneutics in many ways (see, inter alia, Van Aarde 2014). One example is my understanding of the 'kingdom ethics' as expressed in Jesus' parables. This influence filters through 'Ricoeurdian' discernment and my use of pragmatic linguistics. Paul Ricoeur (1913-2005) emphasises the notions of 'imagination' and 'feeling' to articulate the metaphorical process in poetry and rhetoric. According to Ricoeur (1981:233), the metaphor is in essence pictorial. It inspires an association of images that have previously been regarded as unrelated systems of syntheses:

Imagination ... is the ability to produce new kinds by assimilation and to produce them not above the differences, as in the concept, but in spite of and through the differences. (p. 234)

To understand the process of metaphorical interaction, one does not only 'see' but also 'feels' something (Ricoeur 1981:243).

In the late-Romantic version of Affektenlehre, a distinction was made between the concepts 'emotion' (Erfahrung) and 'feeling' (Gefühl). Schleiermacher built on Johann Gottfried von Herder's (1744-1803) ideas on language, hermeneutics, translation, the mind, art and aesthetics and religion (Herder [2006] 2009:29). For Schleiermacher ([1830] [1928] 1976:6-17), emotion ('Erfahrung') is the response to objects, to that which is finite, whereas feeling ('Gefühl') is about, on the one hand, being aware of one's own finitude, and on the other hand, an absolute dependence on that what is the ultimate infiniteness (cf. Grondin 1994:71). This is dependence on the transcendent. It implies involvement, a feeling which Ricoeur (1981:243) calls 'self-assimilation'. It can be propelled by the illocutionary force of a powerful metaphor as a parabolic speech act.

Such a discourse embodies a religious reality articulated by a metaphorical story or narrative. In a metaphorical narrative, the speech act represents analogy (epiphor), but often also disanalogy (diaphor), which presupposes a 'tension of metaphor' (cf. Ricoeur 1975:95-96). This means that the relationship between tenor and vehicle in a metaphor could confirm a view of reality, endorsing the conventional view (epiphor). It can also challenge or subvert the conventional view of reality (diaphor). In other words, in a metaphor, certain entities, either similar (epiphor) or dissimilar (diaphor), are juxtaposed in an interactive process. Through this, new meaning is created.

My understanding of Jesus' kingdom ethics is that of a 'parabolic twist' which witnesses to an 'anti-society' disposition. According to Robert Funk (1966:138), a parable of Jesus redirects attention by means of an imaginative shock'. Jesus' parabolic discourses indicate alternatives to a conventionally ordered society. In Ricoeur's (1974:97-98) terms: 'what is said of the subject is one thing; what I do in saying that is another thing'. For example, 'I may make a mere description, or give an order, or formulate a wish, or give a warning'. According to Ricoeur (1974:100), only 'genuine metaphors are at the same time event and meaning'. 'Event' refers to the creation of a new world as a result of the hermeneutical circularity between text and reader that leads to a fusion of horizons (Horizontverschmelzung). That is congeniality.

\section{Confessional subscription}

Kevin Vander Schel (2013:95) describes Schleiermacher's (CG 2 [1830] 1831; in KGA 1.13.1; 93) view that the particularity of the piety (religiosity) of Jesus-followers, which distinguishes itself from other ways of faith, is that the spirituality of a Jesus-follower ('God-consciousness') relies on 'redemption accomplished through (the historical) Jesus of Nazareth (Schleiermacher [1830-1831] [1960] 2003); he formulates this Grundtatsache as follows:

That Christianity traces its communal life back to Christ is a fact Schleiermacher regards as beyond dispute. The appearance of the Redeemer in history forms the 'basic fact' (Grundtatsache) distinguishing Christianity throughout. Distinctively Christian piety could simply not be possible 'outside of all historical connection with the impulse proceeding from Christ' (mit dem von Christo ausgegangen Impuls). (\$10.1, KGA 1.13.1:81)

This Grundtatsache relates to the quest for the historical Jesus. This 'quest' has often been considered to be the product of the 'quester's' heretical conviction that subverts orthodox Christology. In my personal life, being constantly accused of heresy has become an existential issue. However, I refused to be so branded because of my understanding of the mythical stories about the birth of Jesus. With Schleiermacher, I regard myself as fully in line with Athanasian orthodoxy (see Van Aarde 2016). My reflection on Jesus's birth is based on an exegetical association of a historical-critical and a socialpsychological reading of the relevant ancient texts (see Van Aarde 2004:223-246). This concurs with historical scholarship in almost all major points.

This leads to a reflection on one of the first critical publications of the 19th century, namely, Schleiermacher's romantic-style work, Die Weihnachtsfeier: Ein Gespräch ([1806] 1826). This work was patterned after Plato's Symposium. In English, it is translated as Christmas Eve Celebration: A Dialogue (2010). In this Christmas story in the form of a family dinner celebration with children, parents 
and friends eating, drinking and singing together are presentations of interpretations skilfully portrayed through dialogue (Gespräch). The rationalistically minded lawyer, Leonhardt, churchless but not spiritless, says the following about the 'meaning of Christmas' (Schleiermacher 2010):

Thus, it is obvious that the birth and the actual presence of Christ in history cohere very little with Christianity itself. Yet, that we know all too little about him, it might almost be said, bears just as little certitude, for already at the time when the first reports of him were composed, the opinions were so varied that the authors appear to have taken no notice of how these opinions were themselves to ascertain extent changed from witnesses and reporters among the various parties. Indeed, it can be said that every report and every claim undoes the others. (p. 69, n. 25)

Given the contradicting textual evidence about Jesus' birth in the earliest Christian documents, Schleiermacher's hermeneutics show a greater appreciation for John than for Matthew and Luke (Tice [1990] 2011:59 n. 96). In Schleiermacher's thinking, the author of the Gospel of John can be seen as a 'gifted interpreter' of the Jesus traditions as narrated in the Synoptics. Because of his inner disposition, he succeeded grasping the spirit of the Synoptics (the outer) and writing a new 'history of Jesus' [in Schleiermacher's German: 'die Verknüpfung des Innern und Äußern zu einer geschichtlichen Anschauung'].

Friedrich Hertel (1965:206) describes the existential meaning (Anschauung) of the Weihnachtsfeier as the illustration of divine infiniteness manifested in Jesus' finite humanness 'dass in Christus der Mensch an sich oder das Urbild des wahren Menschen geschichtliches Ereignis geworden ist'. The use of the concept Anschauung here should be seen in its dialectic relationship with the concept Chronik. In some sense, Schleiermacher paved the way for Bultmann's hermeneutics in which a distinction is made between historisch and geschichtlich. Under historisch, Bultmann understands the usual historical factualness of an event, while geschichtlich refers to the existential consequence of such an event. Schleiermacher distinguished between Chronik ('historisch') and Anschauung ('geschichtlich'). The first is investigated by means of a grammatical (technical) analysis ('historical criticism'), and the latter by means of 'psychological interpretation' (an existential 'divine' understanding).

To paraphrase Hertel's profound insight, the Anschauung which Schleiermacher developed in his Christmas Eve Celebration Dialogue centres on the notions 'freedom' (Freiheit) and 'transcendence of human limitless (Unendlichkeit). Transcendence permeates humankind's existential being (Übernahme des menschlichen Daseins), in that it transcends the limitless of life and time (Endlichkeit und Zeitlichkeit). The theology presupposed in the Christmas Eve Celebration Dialogue clearly illustrates this transcendence. Knowing that human beings are longing for liberation (Erlösung) and divine care (Heil), Schleiermacher demonstrates in his Dialogue his Christological understanding - a conceptualisation which escapes the narrowness of existing thought structures. In the
Christmas Eve Celebration Dialogue, one clearly sees that 'Christus der Mensch' has become either in itself and/or in the lives of his followers the Urbild of meaningful life in the midst of the reality of historical events (des wahren Menschen geschichtliches Ereignis) (Hertel 1965:205).

According to Hertel (1965:205), this dialectic between Chronik and Anschauung is articulated in Schleiermacher's ([1806] [1826] 2010) Christmas story in a skilful way. This cannot be illustrated in detail here. A reference to the monologue of the 'churchless' participant Leonhardt in Schleiermacher's narration of a Christmas Eve dinner illustrates such a dialectic between Chronik and Anschauung:

This tradition [the Chronik about Jesus' birth, i.e. God's incarnation through Jesus and the subsequent Anschauung of religious peoples who appropriate Jesus' theōsis - Vergöttlichung], therefore, we shall want to maintain as it has been handed down to us, and the less surely we can explain where in its marvellous power lies, the less eager we will be to change even the least detail in it. For me, at least, even the smallest features are full of meaning. Just as a child is the main object of our celebration, so it is also the children above all who elevate the festival and carry it forth - and through it Christianity itself ... This is my honest opinion, upon which I suggest we touch our glasses and empty them in a toast - a toast to an unending continuation of the Christmas festival. Furthermore, I am all the more certain of your compliance that I hope thereby to makeup for and to wash away everything that may have seemed offensive to you in what I have said. (pp. 70-71)

From an exegetical perspective, Schleiermacher was sceptical with regard to the historical authenticity of the infancy narratives in the Synoptic Gospel tradition. However, this does not mean that he opposed 'confessional subscription' (Schleiermacher 1821-1822:147-148 [§30.1]). Oseka (2015) describes Schleiermacher's view as follows:

Schleiermacher pointed out that the request, that the Bible must be explicated in such a way to suit the confessions, even if it obviously deviates from the historical and literary context of the Scripture, undermines the very principle out of which the Reformation was born ... [H]e realised that at the inception of the Reformation the creeds were not used as means of enslaving the exposition of the Scripture but rather as the temporal and provisional declarations of the biblical message. (pp. 58-59)

According to Pearson (2003:351), Schleiermacher applauded the way in which Athanasius of Alexandria (296-373 CE) and John of Damascus (676-749 CE) interpreted the emphasis in the classical creeds on the relation between the human and the divine in Christ, but avoided 'two-natures language'. Schleiermacher understood Jesus as filled with God-consciousness to such an extent that he could be the example for humankind to absorb the divine into itself (cf. Oseka 2015:40). According to Schleiermacher, the belief of church fathers in Jesus' divinity expresses that Jesus was 'permanently and staunchly conscious of his own dependence on the Absolute', and '[o]n that account that Jesus could be construed as the archetype of the perfect religious self-consciousness which came true in his historical person'. Jesus's salvific meaning pertains to the belief that 
humankind 'can reach exactly the same perfect religious self-consciousness under his influence' (Oseka 2015:40).

Prompted by the narratives about the Jesus of faith, Schleiermacher, in his Christmas celebration, emphasised the importance of conversation, dialogue, criticism, joy, childlike faith and female consciousness with regard to faith. For him the birth of Jesus was not central to 'Christian faith', but rather the 'perfection' ('sinlessness') of Jesus, to which the miraculous birth stories attest. He links Jesus' lack of sin to his God-consciousness. When Christ-followers engage with the 'dialogue of the Christmas celebration', they participate in Jesus' God-consciousness.

For Schleiermacher ([1821-1822] [1830-1831] 1999:397), the relationship between vere homo and vere Deus in the personhood of Jesus manifests sin a God-consciousness in Jesus' humanness. Schleiermacher describes Jesus' humanness ('incarnation') as the 'supernatural-becoming-natural' (Naturwerden des Übernatürlichen) (see Vander Schel 2013:11 n. 25). Similarly, 'God is present in all other human beings', although 'to a far greater degree' in Jesus (p. 364).

This is why Schleiermacher speaks of Jesus as both an Urbild and a Vorbild (cf. Resch 2012:26).

Resch (2012) rephrases Schleiermacher as follows:

When the early disciples perceived the perfection of Christ, their own consciousness of God was awakened and developed. In turn, the proclamation of the sinless Christ by the first disciples had a similar effect on others, thus perpetuating the redemptive work of Christ through history. (p. 27)

This means that Jesus had the ability to impart Godconsciousness to others. Christ-followers can participate in this God-consciousness (Clements 1987:57) when they re-tell the stories of his birth in whatever genre, be it sermons, liturgical hymns, confessional creeds, poetry, film or novels.

I therefore find the dispute among exegetes unfortunate (e.g. Kennedy 2018:137-139) for, or (e.g. Paula Frederiksen 2017:165) against the 'belief' that 'Jesus is God', mostly based on Pauline texts such as Philippians 2:5-11 and Romans 1:3-4. The concept theōsis ( $\theta \dot{\varepsilon} \omega \sigma 1 \varsigma)$ is about the shared substance between Jesus and the Godhead. It signifies the absorption of the divine into human existence. Sharing divine substance by human beings signifies a life which embodies God's wisdom, justice and mercy. The concept theosis signifies the absorption of Jesus's life into the lives of his followers, whether they were Paul and the 'evangelist John' who was responsible for the gist of the 'Fourth Gospel' - or whether they were Athanasius of Alexandria or John of Damascus, or Friedrich Schleiermacher.

As said earlier in this essay, it is Schleiermacher who has become to be my role model and helped me to understand my own longing for sharing the divine substance embodied by Jesus and proclaimed by Paul and John in the
New Testament. This is the message of creedal Christianity which I would like to endorse - as it was the case with Friedrich Schleiermacher.

\section{Acknowledgements}

This article is a substantial reworking (more than $70 \%$ of the original) and amalgamation of four articles:

- Pelser, G.M.M. \& Van Aarde, A.G., 2007, 'The historicalhermeneutical prelude to the legacy of Karl Barth', HTS Theological Studies 63(4), 1347-1375.

- Van Aarde, A.G., 2003, 'The Christmas Eve Dialogue of Friedrich Schleiermacher in Afrikaans: Background, translation and hermeneutics', HTS Theological Studies 59(2), 545-568.

- Van Aarde, A.G., 2015, 'Progress in psychological biblical criticism', Pastoral Psychology 64, 481-492. https://doi. org/10.1007/s11089-014-0636-y

- Van Aarde, A.G. \& Van Wyk, T., 2016, “"Doctor of the Academy": Ernst Fuchs', HTS Theological Studies 72(1), a3357. https: / / doi.org/10.4102/hts.v72i1.3357

\section{Competing interests}

The author declares that they have no financial or personal relationships which may have inappropriately influenced them in writing this article.

\section{Author's contributions}

A.G.V.A. is the sole author of this article.

\section{Ethical considerations}

This article followed all ethical standards for research without direct contact with human or animal subjects.

\section{Funding information}

This research received no specific grant from any funding agency in the public, commercial or not-for-profit sectors.

\section{Data availability statement}

Data sharing is not applicable to this article as no new data were created or analysed in this study.

\section{Disclaimer}

The views and opinions expressed in this article are those of the author and do not necessarily reflect the official policy or position of any affiliated agency of the author.

\section{References}

Arendt, A., 2010, 'Schleiermacher: Dialectic and transcendental philosophy, relationship to Hegel', in B.W. Sockness \& W. Gräb (eds.), Schleiermacher, the study of religion, and the future of theology: A transatlantic dialogue, pp. 349-360, Theologische Bibliothek Töpelmann, De Gruyter, Berlin.

Barth, K., [1952] 1972, Protestant theology in the nineteenth century: Its background\& history, transl. J. Bowden, SCM Press, London. 
Barth, K., [1968] [1978] 1982, The theology of Schleiermacher: Lectures at Göttingen, winter semester of 1923/4, D. Ritschl (ed ), and transl. G.W. Bromiley, T\&T Clark, Wdinter sem.

Christensen, C.B, [1998] [2004] 2018, Dilthey on hermeneutics and the understanding of others, viewed 26 October 2018, from http://cbchristensen.net/courses/ dilthey/dilthey-on-hermeneutics-and-the-understanding-of-others/.

Clements, K., 1987, FriedrichSchleiermacher: Pioneerofmoderntheology, Collins, London.

Crouter, R., 2005, 'Signposts of a public theologian', in R. Crouter (ed.), Friedrich Schleiermacher: Between enlightenment and romanticism, pp. 123-194, Cambridge University Press, Cambridge.

Dilthey, W., [1894] 1977, 'Ideas concerning a descriptive and analytic psychology', in W. Dilthey (ed.), Descriptive psychology and historical understanding, Springer, Nijhoff, Dordrecht. https://doi.org/10.1007/978-94-009-9658-8_2

Dumbreck, G., 2012, Schleiermacher and religious feeling, Studies in Philosophical Theology 49, Peeters, Leuven.

Frederiksen, P., 2017, Paul: The pagans' apostle, Yale University Press, New Haven, CT.

Funk, R.W., 1966, Language, hermeneutic, and word of God: The problem of language in the New Testament and contemporary theology, Harper \& Row Publishers, New York.

Grondin, J., 1994, Introduction to philosophical hermeneutics, Yale Studies in Hermeneutics, foreword by Hans-Georg Gadamer, transl. J. Weinsheimer, Yale Hermeneutics, foreword by Hans
University Press, New Haven, CT.

Herder, J.G., [2006] 2009, 'Introduction', in G. Moore (ed.), Johann Gottfried Herder: Selected writings on aesthetics, transl. G. Moore, pp. 1-30, Princeton University Press, Princeton, NJ.

Hertel, F., 1965, Das theologische Denken Schleiermacher's, ZwingliVerlag, Zürich.

James, W., [1902] 2012, The varieties of religious experience: A study in human nature, Oxford World Classics, Oxford University Press, Oxford.

Kazen, T., Heschel, S., Van Aarde, A., Parrish, J.W. \& Moxnes, H., 2016, 'Discussion of the book of Halvor Moxnes, Jesus and the rise of nationalism', Annali di stories dell' esegesi (ASE) 30(1), 193-234

Kennedy, L.J., 2018, 'Paul: The pagans' apostle, by Paula Frederiksen', Kesher: A Journal of Messianic Judaism 32, 133-138.

Lang, E., 1873, 'Überdie Psychologievon Schleiermacher', PhD dissertation, University of Jena, Berlin, viewed 27 October 2013, from http://www.archive.org. UniversityofToronto-RobartsLibrary.

Moxnes, H., [2009] 2016, 'What is it to write a biography of Jesus? Schleiermacher's Life of Jesus and nineteenth-century nationalism', in H. Moxnes, W. Blanton \& J.G. Crossley (eds.), Jesus beyond nationalism: Constructing the historical Jesus in a period of cultural complexity, pp. 27-42, Routledge, London

Moxnes, H., 2012, Jesus and the rise of nationalism: A new quest for the nineteenth century historical Jesus, I.B. Tauris, Chicago, IL.

Oseka, M., 2015, 'An equilibrium: Schleiermacher's insights into the confessional subscription in its historical setting', Juan Dao: A Journal of Bible \& Theology 43 , 33-72.

Otto, R., [1917] [1923] 1958, The idea of the Holy: An inquiry into the non-rational factor in the idea of the divine and its relation to the rational, transl. J.W. Harvey, factor in the idea of the divine and
Oxford University Press, Oxford.

Pearson, L., 2003, 'Schleiermacher and the Christologies behind Chalcedon', Harvard Theological Review 96(3), 349-367. https://doi.org/10.1017/S001781 6003000476

Resch, D., 2012, Barth's interpretation of the virgin birth: A sign mystery, Barth Studies, Ashgate, Burlington.

Richardson, D., 1991, The role of women in the life and thought of the early Schleiermacher (1768-1806): An historical overview, Schleiermacher Studies and Translations 7, Edwin Mellen, Lewiston, NY.
Ricoeur, P., 1974, 'Metaphor and the main problem of hermeneutics', New Literary History 6(1), 95-110, John Hopkins University Press, viewed 25 March 2014, from http://www.jstor.org/discover/10.2307/468343? uid=2\&uid=4\&sid=211046 from http://w

Ricoeur, P., 1975, 'Biblical hermeneutics', Semeia 4, 29-145.

Ricoeur, P., 1981, 'The metaphorical process as cognition, imagination, and feeling', in M. Johnson (ed.), Philosophical perspectives on metaphor, pp. 228-247, University of Minnesota Press, Minneapolis, MN.

Rollins, W.G., 2015, 'Response to the panel review of psychological hermeneutics for biblical themes and texts: A festschrift in Honor of Wayne G. Rollins', Pastoral Psychology 64, 507-514. https://doi.org/10.1007/s11089-014-0608-2

Schleiermacher, F.D.E., 1821-1822, Diechristliche Glaubenachden Grundsätzenderevangelische Kircheim Zusammenhangdargestelt, vol. 1-2, Reimer, Berlin.

Schleiermacher, F.D.E., [1927-1928] 1985, Die Algemeine Hermeneutik, W. Virmond (ed.), Schleiermacher-Archiv, vol. 1, pp. 1271-1230, DeGruyter, Berlin.

Schleiermacher, F.D.E., [1819] [1864] 1997, The life of Jesus, Lives of Jesus Series, J.C. Verheyden (ed.), Sigler Press (original from Pennsylvania State University), digitised 14 October 2011, Mifflintown, PA.

Schleiermacher, F.D.E., [1821-1822] [1830-1831] 1999, The Christian faith, transl. H.R. Mackintosh \& J.S. Stewart, T\&T Clark, Edinburgh.

Schleiermacher, F.D.E., [1830] [1928] 1976, The Christian Faith, Transl. of the Second Edition by H.R. Mackintosh \& J.S. Stewart, T \& T Clark, Edinburgh.

Schleiermacher, F.D.E., [1830-1831] [1960] 2003, Der christliche Glaube nach den Grundsätzen der evangelische Kirche im Zusammenhange dargestellt [CG2], 2nd edn., in Kritische-Gesamtausgabe [KGA], R. Schäfer (ed.), Walter de Gruyter, New York.

Schleiermacher, F.D.E., [1806] [1826] 2010, Christmas Eve celebration: A dialogue, transl. T.N. Tice, Cascade Books, Eugene.

Sydnor, J.P., 2011, Ramanuja and Schleiermacher: Toward a constructive comparative theology, Princeton Theological Series, Pickwick Publications, Eugene, OR.

Tice, T.N., [1990] 2011, 'Church history: On viewing Christianity historically', in F.D.E. Schleiermacher (ed.), Brief outline of theology as a field of study, 3rd edn., revised translation of the 1811 and 1830 editions, with essays and notes by T.N. Tice, pp. 58-60, Westminster John Knox, Louisville, CT.

Van Aarde, A.G., 1989, Hand 7:48 - 'Die Allerhoogste woon nie in mensgemaakte konstruksies nie...': Die relevansie van die Nuwe-Testamentiese wetenskap na aanleiding van die metafoor 'tempel', Universiteit van Pretoria Nuwe Reeks $\mathrm{Nr}$ 259-1989, Van Schaik's Boekhandel, Pretoria.

Van Aarde, A., 2003, 'Die ou-Kersaandgesprek van Friedrich Schleiermacher in Afrikaans: Agtergrond, vertaling en hermeneutiek', HTS Teologiese Studies/ Theological Studies 59(2), 545-568. https://doi.org/10.4102/hts.v59i2.652

Van Aarde, A.G., 2004, 'Social identity, status envy, and Jesus as fatherless child', in J.H. Ellens \& W.G. Rollins (eds.), Psychology and the Bible: A new way to read the scriptures, vol. 4, pp. 223-246, Praeger, Westport, CT.

Van Aarde, A.G., 2014, 'Pragmatic dimensions in parable research and the divine economy of the basileia', HTS Theological Studies 70(1), Art.\#2688, 1-11. https:// doi.org/10.4102/hts.v70i1.2688

Van Aarde, A.G., 2015, 'Progress in psychological biblical criticism', Pastoral Psychology 64, 481-492, https://doi.org/10.1007/s11089-014-0636-y

Van Aarde, A.G., 2016, 'DNA in antiquity: Revisiting Jesus's birth', Neotestamentica 50(3), 29-58. https://doi.org/10.1353/neo.2016.0018

Van Aarde, A.G. \& Van Wyk, T., 2016, “'Doctor of the academy": Ernst Fuchs', HTS Theological Studies 72(1), a3357. https://doi.org/10.4102/hts.v72i1.3357

Van Aarde, A., 2018, 'Reflective perspectives on Paul', HTS Teologiese Studies/ Theological Studies 74(4), a5248. https://doi.org/ 10.4102/hts.v74i4.5248

Vander Schel, K.M., 2013, Embedded grace: Christ, history, and the reign of God in Schleiermacher's dogmatics, Emerging Scholars, Fortress, Minneapolis, MN.

Van Wyk, T. \& Van Aarde, A., 2016, "Doctor of the Church": Gerhard Ebeling', HTS Theological Studies 72(1), a3353. https://doi.org/10.4102/hts.v72i1.3353 